P443. 2. 004. 1

\title{
螢光染料の人体安全性
}

\author{
日本化薬株式会社王子染料工場 商品開発課 山内靖夫，清水義秋
}

\section{Safety of Fluorescent Whitening Agents to Human Bodies}

\author{
Yasuo Yamauchi and Yoshiaki Shimizu \\ Product Application and Development Section of Oji Dyestuff Works \\ of Nippon Kayaku Co., Ltd.
}

Fluorescent whitening agents (FWAs) have been manufactured since 1950 in Japan. Now, they are used very widely in the fields of paper, textile, and detergent industries.

Discussions were given to the results of medical surveys and studies on the safety of the FWAs derived particularly from diaminostilbene disulphonate. The FWAs can be considered to be safe both in chronic and acute toxicities.

Further, possibility of the FWAs' contamination to human skin or table-wares from papers and textiles was examined. The results showed that the degrees of contamination were very small or negligible.

As a conclusion, the FWAs are practically nontoxic even if they are taken into human bodies, though they can not migrate to human skin from papers or textiles containing the FWAs.

\section{1. まえがき}

螢光染料は，物質を増白するための染料であるが， 人体と直接触れる紙ならびに衣料製品に広く用いられ るので，その安全性は極めて重要な問題である。同時 にこれは，製紙あるいは染色工場にとっても，また染 料メーカーにとっても作業者の安全衛生という点から やはり最も重要な問題である。

近年, 化学品の人体安全性と環境污染の問題が消費 者運動の一環として大きく取り上げられてきたことは， 意義あることである。最近の螢光染料の安全性に対す る関心も，われわれの生活にかかわる重要問題に対す る問題意識の一つの現れと理解される。螢光染料の人 体障害の可能性については，古くから世界各国で研究 され，膨大な研究報告特よび調査結果が報ぜられてい る。これら資料については，化成品工業協会䖝光染料 委員会 ${ }^{1)}$, 前松(2) 扣よび赤松・松尾ら ${ }^{3)}$ の報文に詳し い。螢光染料は 20 年以上にわたる工業生産と合成研 究の歴史の中で, 没学的無毒性が支持されて特り, ま た広範な動物実験に括いても毒性が検出されないので， 極めて安全な化学品といえよう。本報では，一部他の 報文と重複するが，螢光染料の使用の現状，医学的な 調査/研究結果, 紙や繊維製品からの人体または食器
ヘの移染性などについて，われわれの知見の範囲で検 討を加觉てみたい。

\section{2. 螢光染料の歴史と使用の現状}

螢光染料は 1929 年ドイッの P. Krais が西洋とちの 木の樹皮から得た Aesculin が契機となって開発され たものである。わが国では第二次大戦後ヨーロッパか らの輸入品が使われ始め，その後 1950 年に国産化さ れて以来急速に需要を増し, 紙, 繊維および洗剂など に幅広く使用されてきた。近年の日本に拉ける需要量 (内需) は, 昭和 43 年 $6,000 t, 45$ 年 $7,300 t$ そして 47 年 8,500 t であるが，各需要分野の使用割合は扣物 よそ紙 35\%，繊維 35\%和よび洗剂 30\%である。䖝光 染料の消費量が年々増大するのは，紙，績維および洗 剂の生産量の増大に対応したものである。

䖝光染料はその用途に応じ，いくつかの母体構造を 異にするものが使われているが，実用最大濃度は，一 般に紙ではパルプ重量に対して $0.4 \%$ 程度，繊維では その重量に対し $0.3 \%$ (セルロース) $2 \%$ (合成繊維) でまた洗剤には約 $0.5 \%$ 配合されている。

䖝光染料の需要量をその構造系別に見ると，ジアミ ノスチルベン・ジスルホン酸型の染料が圧倒的多量を 占め，他のものは相対的にかなり少い。これはジアミ 


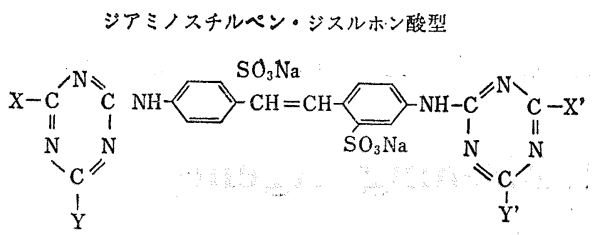

クマリン型

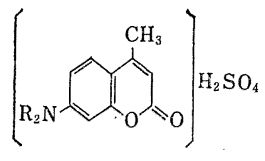

ピラゾリン型

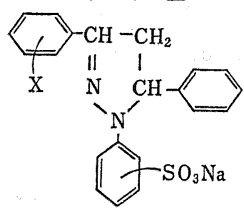

型

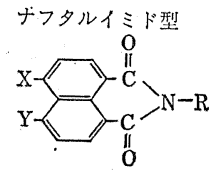

図 1 管光染料の代袁的な化学構造

ノスチルベン・ジスルホン酸型がセルロース，タンパ ク質特よびポリアミドなど広範な物質に優れた染着性 を有し，一方他の型のものは特定の物質（ポリエステ ルポリアクリロニトリルなど）にしか適性を示さな いためである。

\section{3. 螢光染洲の人恗安全性}

㐫る物質が人体に有害か無害かを決的るとは非常 に難しい問題である。といらのは，例えばわれわれの 食生活汇不可欠な食塩も過剩に摂取すれば健康障害を もたらすよらに，ぞんな物質でも㩒取量が多くなれば 何らかの毒性を示すからである。もら一つの理由は, 現在の科学技術では, 摂取物之健康障害の因果関係が 必ずしも明確にできないからである。化学品の人体安 全性問題は，これらをよく踏えた上で考光る必要があ り，換言すれば安全性の評洒基準が非常に重要である。 螢光染料の医学的研究の詳細は他の文献1),2)、3にゆ ずるとして，ここではこれまでに得られた調査結果と 研究データを疫学的立場から,ならびにWHO (World Health Organization 世界保健機構) と FAO (Food \& Agriculture Organization 食糧農業機構) の提唱 する安全率の立場から考察してみたい。

\section{1 螢光染料の製造作業者および 研究者に対する 調査結果}

最近のわが国の公害裁判で，因果関係を証明する有
力な決め手として疫学的手法が援用されている。これ は科学的証明の難しい因果関係を, 確率論の立場から 統計的に立証せんとする方法であり，事実関係を説明 する新しい合理的な考方方である。

わが国の䖝光染料の工業生産は1950年に始をり, 1953 年汃ら本格的な大量生産が行なわれて 現在飞至 っている。この間生産された数量は数万 $\mathrm{t}$ 以上にのほ り，生産に從事した作業者と合成研究に携った人の数 は何千人にも扣よぶと推定される。これらの人々の間 での職業性疾患の発生率は, 螢光染料の安全性を見る 上で重要な指標となる。

科学技術庁資源調査所資料4)によれば，矢部・林ら 5) は 1950〜1955 年にわたりトリアジル人チルベン系 䖝光染料の合成ならびに性能研究を継続し，特に合成 段階では，これら染料の濃厚溶液あるいは固体之直接 皮膚接触の機会を数多く経験したが，当時ならびに現 在 (1960年) に和いても何らの炎症や異状を認めてな い。また，染料製造に和ける螢光染料の合成現場の作 業員についての身体の異状や障害は，今日までのとこ ら認められていないとのことである。

化成品工業協会 6 ） 女日本の大手染料メーカー 6 社の 名の下に，1950 年の生産開始以来營光染料に起因す ると見られる労衝衛生上の事故者は 1 名も発生してな いと報じている。外国に执いても，D.A.W. Adams ${ }^{7)}$ は Hickson \& Welch 社 (英国) の例として，数年 以上にわたって大量の螢光染料を取扱っている作業者 の中に有害の徵候を示す 1 件の症例もなかったと述べ ている。

また，䖝光染料の主要原料である $4,4^{\prime}$-ジアミノス チルベンー2, 2'ージスルホン酸から合成される染料は, 螢光染料以外にもあり今世紀初頭から作られているが， 日本より数十年古い染料工業の歴史を歹つ西欧に和い て，これら染料に関する薬害発生の報告はない6。

これらの諸事実は，䖝光染料の度学的安全性を支持 するものと理解される。つまり，䖝光染料はベンジジ ンやベータ・ナフチルアミンなど発ガン作用を示す物 質とは根本的に異る安全な化学品ということができよ う。なお，大高 ${ }^{8)}$, 青山 (新聞投書) ${ }^{9)}$ が肌着による皮 膚発疹やカブレを報告しているが，新品着用時だけの 問題で洗灌後に解消したことから察すれば, 原因は螢 光染料以外のものになろら。といらのは, 繊維上の䖝 光染料は後述のよらに容易に皮膚移染しないし，また 家庭用合成洗剂には $0.5 \%$ 程度の螢光染料が 通常配合 されているからである。

\section{2 化学構造}

人体皮膚に接触するノート，伝票などの紙製品およ 
び下着，ワイシャツなどの繊維製品に最も広く使われ ているのは, ジアミノスチルベン・ジスルホン酸型の 䖝光染料なので, この型の染料の安全性は最も重要な 問題である。

この染料の中間物 $4,4^{\prime}$-ジアミノスチルベン $-2,2$ ' ジスルホン酸が，発ガン性をもつとい和る4-アミ ノスチルベンと見かけ上類似構造るもことから，一 時乞の発がン性を疑われたことがあった。しかし，寺 山9) は薬理学的な立場からガン原性は非常に小さいと 診断し, さらに他の研究結果 (後述)でもその発ガン 性は否定されている。李た，一つの危険な可能性とし て䖝光染料の筊造工程中で 4-アミノスチルベンが副 生乙染料製品中に混入することが考光られるが，工程 的汇見てこの可能性も全〈否定されている11。従って, ジアミノスチルベン・ジスルホン酸型の染料は化学構 造的に見ても有害の䯚念はないと考光られる。

な拉，最近 5 ーニトロアセナフテンの発ガン性が橋 田ら ${ }^{111}$ によって指摘されたが，このものは䖝光染料の 原料として全く使学れて和らず，かつ工程上副生する 可能性もないので特に問題はないとい方る。

\section{3 医学実験結果と安全性}

䖝光染料，とり方けジアミノスチルベン・ジスルホ ン酸系の染料は，われわれの口や皮膚を通して摂取さ れる可能性が岗るので，その医学実駼結果注目する 必要がある。数多くの実験が，急性害性，亜急性毒性， 慣性毒性叔よび代謝などについて経口または経皮投与 で行なるれ，なが沈皮下，腹腔内岁るいは静脈注射 によって行なわれた妇のる㐫る。これら医学文献の内 容は原文宗たは抄録1，2，3）穵参照されたい。

\section{3.1 急货搳惟}

物質の急性毒性の程度は $\mathrm{LD}_{50}$ 值で表されることが 多い。 LD 50 (Lethal Dose 50\%) とは; 動物実験飞牱 いて1回投与で半数の㗢物が死亡した時の投与量であ って，体重 $1 \mathrm{~kg}$ 当りに換算して表した量である。 米国工業衛生拹会 (American Industrial Hygiene Association）は急性毒性の分類基準を表 1 の上うに 定めている12)。

䖝光染料の経口急性毒性は, マウス, ラット, モル モット拉よびウサギなどについて報告されているので， これを家庭用品との対比で弄 2 亿揭げる。ここで○○ $\mathrm{g}$ 以上との表示ふ，○○g末でしか実験されていない との意である。これらの結果から見ると，䖝光染料の 毒性水準はランク 5 またはランク 6 でわれわれの日用 品にくらべ少なくとも同程度の安全性をるっているも の之理解される。な和，経皮投与の急性毒性は，10 g 以上/ $\mathrm{kg}$ (ジアミノスチルベン・ジスルホン酸型), $8 \mathrm{~g}$ 昭和 48 年 11 月
表 1 ，急性毒性分類（米国工業衛生協会）

\begin{tabular}{|c|c|c|c|}
\hline ランク & 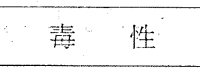 & $\begin{array}{l}\text { 経口 } \mathrm{LD}_{50} \\
\text { (ラット) }\end{array}$ & 物 質 例 \\
\hline 1 & $\begin{array}{l}\text { Extremely } \\
\text { toxic } \\
\text { (極㱛て有毒) }\end{array}$ & $1 \mathrm{mg}$ 以下 & . \\
\hline 2 & $\begin{array}{l}\text { Highly toxic } \\
\text { (かがり有毒). }\end{array}$ & $1 \sim 50 \mathrm{mg}$ & \\
\hline 3 & $\begin{array}{l}\text { Nioderately } \\
\text { toxic } \\
\text { (やや有毒) }\end{array}$ & $50 \sim 100 \mathrm{mg}$ & \multirow{2}{*}{ 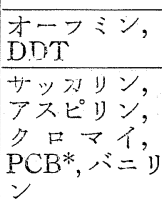 } \\
\hline 4 & $\begin{array}{l}\text { Slightly toxic } \\
\text { (僅弥江有毒) }\end{array}$ & $0.5 \check{5} \sim \bar{g}$ & \\
\hline 5 & $\begin{array}{l}\text { Practically } \\
\text { nontoxic } \\
\text { (汪とんど無害) }\end{array}$ & $5 \sim 15 \mathrm{~g}$ & $\begin{array}{l}\text { Y } \\
\text { 食塩, } \\
\text { エタール }\end{array}$ \\
\hline 6 & $\begin{array}{l}\text { Kelativejy } \\
\text { harmless } \\
\text { (無害) }\end{array}$ & $15 \mathrm{~g}$ 以上 & 砂糖 \\
\hline
\end{tabular}

**゚リ塩化ビフニニル

表2 䇺光染料および家庭用品の経口急性毒性

\begin{tabular}{|c|c|c|c|c|}
\hline \multicolumn{2}{|c|}{ 試 料 } & $\begin{array}{c}\mathrm{LU}_{50}: \\
\mathrm{g} / \mathrm{kg}\end{array}$ & 実験動物 & 文献 \\
\hline \multirow{4}{*}{$\begin{array}{l}\text { 䖝 } \\
\text { 光 } \\
\text { 染 } \\
\text { 料 }\end{array}$} & 紙＼cjkstart用 & 10以上 & マウス & 3), 14) \\
\hline & 木 綿 用 & $\begin{array}{l}3 \text { 以上 } \\
\sim 10 \text { 以上 }\end{array}$ & マウス & 3), 13) \\
\hline & 羊 毛 周 & 10以上 & マウス & 3) \\
\hline & 洗 斉 用 & 10以上 & $\begin{array}{l}\text { マウス, } \\
\text { ラット, } \\
\text { ウサギ }\end{array}$ & 3), 15) \\
\hline \multirow{6}{*}{$\begin{array}{l}\text { 萣 } \\
\text { 庭 } \\
\text { 用 } \\
\text { 品 }\end{array}$} & 食塩（食卓塩） & $3 \sim 6$ & ラット & 16) \\
\hline & ふくくらし粉 & $3 \sim 4$ & ラット & 16) \\
\hline & $\begin{array}{l}\text { タルタルクリ } \\
\text { 一ム }\end{array}$ & $10 \sim 22$ & ラット & 16) \\
\hline & $\begin{array}{l}\text { 砂糖（グラニ } \\
\text { ュ一糖） }\end{array}$ & $23 \sim 32$ & ラット & 16) \\
\hline & 化粧石襝 & $6 \sim 16$ & ラット & 16) \\
\hline & 紙巻タバュ & $3 \sim 4$ & ラット & 16) \\
\hline
\end{tabular}

* 家庭用品の值は $\mathrm{LD}_{0}$ (最大無致死量) MLD (最少致死量)

以上 $/ \mathrm{kg}(\text { (ピラン゙リン・スルホン酸型 })^{3)}$ といわれ，こ の場合も活とんど無毒性を示している。

\section{3 .2 慢性害性と「荌全率」}

一時的な多量摂取で安全な物質でも，少量づつ長期 間汸たって摄取される場合飞，生体内蓄積されて 毒性を現わすことがある。これが慢性毒性であり, 最 も恐れられるのが覀性腫漡とりわけガンの発生といわ れる。

䖝光染料は，人体皮膚倿触しても，内部のケラチ ン層をで移行せず表皮最上層にとどをることが確かめ られている177,18)。また，ネコの腹腔内に投与した場 合は，初回尿に气の大部分が排泄され最終的には注と 
んど全量が排泄されること，および経口投与に执いて も同様であることが報告されている19)。したがって， $\mathrm{PCB}$ (ポリ塩化ビフェニル) などに見られる生体内で の蓄積性は，䖝光染料の場合は否定される。

WHO (世界保健機構) 特よび FAO (食糧農業機構) の提唱する食品衛生上の安全性に関する考え方 ${ }^{20)}$ ，な らびに米国 FDA (Food \& Drug Administration 食 品医薬品管理庁）の食品涯加物法規 ${ }^{21)}$ は，慢性毒性を 最も重視し，安全性の尺度の一つとしてつぎの式で表 わされる「安全率」を導入している。

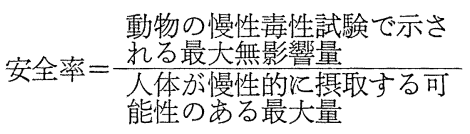

つまり，動物実験で得られる最大無影響量が，人の 摂取する可能性のある最大量の何倍であるがよって 安全性の程度を表わすものである。この場合,

安全率 $\geqq 100$

の時记安全と見なされる。「100」は動物種間差係数々 $\lceil 10 」 ，$ 個体差係数を「10」とした時の両係数の積で あるが，動物実験から人体安全性を予測する場合，少 なくとも 100 倍の安全率を見込む必要のあることを意 味する。

ジアミノスチルベン・ジスルホン酸型螢光染料の安 全性をこの考え方から追求してみたい。人体の最大可 能摂取量の算出はかなり難しいが，仮に下着から体内 に移染するものと想定（前述のように実際にはあり得 ない，後記参照）してつぎのように求めてみよう。

着用下着 (成人)：半袖メリヤスシャツ（1枚）

$$
\begin{aligned}
& 150 \mathrm{~g} \text { パンツ（1枚） } 70 \mathrm{~g} \text { ロングパ } \\
& \text { ンツ（1枚） } 150 \mathrm{~g} \\
& \text { 計 } 370 \mathrm{~g}
\end{aligned}
$$

下着中の螢光染料: $0.2 \%$ 対繊維重量として

$$
370 \mathrm{~g} \times 0.2 \%=0.77 \mathrm{~g}
$$

人体移染量 : 成人体重 $60 \mathrm{~kg}, 1$ 年間 $(360$

日）の着用で全染料の $1 / 4$ が移染すると仮定
して，体重 $1 \mathrm{~kg}$ 当りの摂取量は $0.77 \mathrm{~g} \times 1 / 4$ $\div 365$ 日 $\div 60 \mathrm{~kg}=0.009 \mathrm{mg} / \mathrm{kg} /$ 日

動物に特ける慢性毒性試験内容を表 3 に揭げる。い ずれの報告者も, 内蔵器官の解剖所見を含め, 何らの 異状子認められなかったと述べている。発ガン性およ び自然発生に対する相互発ガン性, 腫瘍の発生, 中毒 症状など螢光染料に起因すると見られる障害は全く認 められてない。

これら実験の投与量は上述の意味から最大無影響量 以下のものであるが，経口投与の場合について前記安 全率を求めればつぎの通りである。

$$
\begin{aligned}
\text { 安全率: S. Neukomm } & 20 \mathrm{mg} \div 0.009 \mathrm{mg}=2,200 \\
\text { F. Hoffmann } & 5 \mathrm{mg} \div 0.009 \mathrm{mg}=556 \\
\text { C. Gloxhuber } & 0.82 \mathrm{~g} \div 0.009 \mathrm{mg}=9,110 \\
\text { C. Gloxhuber } & 1.54 \mathrm{~g} \div 0.009 \mathrm{mg}=17,110
\end{aligned}
$$

いずれの場合も安全率が 100 より著しく犬さいこと が注目される。これらの值は实際には生じ得ない染料 の人体移染を仮定した時のものであり，をた動物実験 の最大無影響量以下の值を基礎にしていることを考慮 すれば，実際の安全率はさらに高い值であろらと推察 される。この結果は前記した疫学的調査結果を医学実 験的に裏付けるものと理解される。

\section{$3,3.3$ 人体実験}

人体を対象とした実験研究は，主に皮膚障害につい

\begin{tabular}{|c|c|c|}
\hline 報 告 者 & $\begin{array}{l}\text { 実験 動物 } \\
\text { (体重 } \mathrm{g})\end{array}$ & 投 与 \\
\hline S. Neukomm $5^{22)}$ & $\begin{array}{l}\text { ハツカネズ } \\
\text { ミ(25g) }\end{array}$ & $\begin{array}{l}5 \mathrm{mg} \text { 皮下注射後, 飭料にて経口投与。 } 0.5 \mathrm{mg} / \\
\text { 匹 } / \text { 日 }(=20 \mathrm{mg} / \mathrm{kg} / \text { 日 })\end{array}$ \\
\hline F. Hoffmann $5^{23)}$ & ラット & $\begin{array}{l}\text { 飲料水にて経口投与。 } 2 \mathrm{mg} / \mathrm{kg} / \text { 日・ } 10 \text { 日 } \rightarrow 4 \mathrm{mg} / \\
\mathrm{kg} / \text { 日・ } 4 \text { 週間 } \rightarrow 5 \mathrm{mg} / \mathrm{kg} / \text { 日 合計 } 2 \text { 年間 }\end{array}$ \\
\hline C. Gloxhuber $5^{19)}$ & ラ $(50 \mathrm{~g})^{\mathrm{r}}$ & 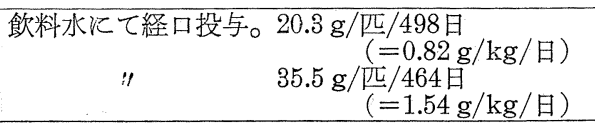 \\
\hline F.H. Snyder $5^{15)}$ & $\begin{array}{l}\text { Mツカネズ } \\
\text { ミ(25g) }\end{array}$ & $\begin{array}{l}\text { 経皮投与 } \\
111 \text { 週 }\end{array}$ \\
\hline
\end{tabular}
て広く行なわれている。報文の紹介11,3) は割愛するが 結論は一般に無害と見られている。もっとも疫学的調 查結果は，結果的にさまざすな環境条件下での人体実 験結果を集約したものと考光ることがでさよう。

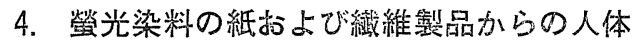 および食器に対桨る移染性}

表 3 䖝光染料の慢性毒性試験：動物実験
螢光染料が人体皮顱に 触れた場合，皮下への浸 透桩散がないといわれて いることは先に述べた。 しかし，螢光染料を含む 緍和よび繊維製品が人体 や食器に接触する時, ぞ の程度移染する可能性が あるかといらことは興味 ある問題であり，調査す る必要があろらと思われ た。われわれは，デパー 
トなどから買求めた市場の紙製品についてこれらの実 験を行なってみた。

\section{1 紙製品からの人体移染性}

䖝光染料が一般に使われている紙製品として表 4 に 揭げる上質紙，コート紙执よび家庭用薄葉紙をとり上 げ，人体と接触した場合の螢光染料の移染の可能性を 試験した。䖝光染料の移染度ならびに溶出度の判定は， 厚生省告示昭 41 一第285 号生理処理用品基準で規制さ れた䖝光強度を基準として行なった。

表 4 供試紙製品：一般市場品

\begin{tabular}{|c|c|c|c|c|}
\hline $\begin{array}{l}\text { 試料 } \\
\text { No. }\end{array}$ & 紙種 & xーカ & 増白法* & 主な用途 \\
\hline $\begin{array}{l}1 \\
2 \\
3 \\
4\end{array}$ & $\begin{array}{c}\text { 上質紙 } \\
\text { (A) }\end{array}$ & $\begin{array}{l}A \text { 社 } \\
B \text { 社 } \\
C \text { 社 } \\
C \text { 社 }\end{array}$ & $\begin{array}{l}\text { ビーター } \\
\text { ビーター } \\
\text { ビーター } \\
\text { サイズプ } \\
\text { レス }\end{array}$ & $\begin{array}{l}\text { 図画用紙 } \\
\text { 特封筒 } \\
\text { 特封筒 } \\
\text { 特封筒 }\end{array}$ \\
\hline 6 & $\begin{array}{c}\text { コート紙 } \\
\text { (B) }\end{array}$ & $\begin{array}{l}\mathrm{D} \text { 社 } \\
\mathrm{C} \text { 社 }\end{array}$ & $\begin{array}{l}\text { コーティ } \\
\text { ング } \\
\text { コーティ } \\
\text { ソグ }\end{array}$ & $\begin{array}{l}\text { 高級印刷用紙 } \\
\text { 高級印刷用紙 }\end{array}$ \\
\hline $\begin{array}{l}7 \\
8 \\
9\end{array}$ & $\begin{array}{l}\text { 家庭用 } \\
\text { 溥葉紙 }\end{array}$ & $\begin{array}{l}F \text { 社 } \\
F \text { 社 } \\
G \text { 社 }\end{array}$ & $\begin{array}{l}\text { ビーター } \\
\text { ビーター } \\
\text { ビーター }\end{array}$ & $\begin{array}{l}\text { 京花(高級チリ紙) } \\
\text { 一般チリ紙 } \\
\text { 一般チリ紙 }\end{array}$ \\
\hline
\end{tabular}

*螢光染料はいずれの試料もジアミノスチルベン・ジスルホン酸型の 水溶珄染料

\subsection{1 試験方法}

紙製品から䖝光染料が人体移染する過程にはつぎの 3 つが考えられる。

a）機械的接触による

b）人体分泌液などに一旦溶出し，これが人体に 染着する

c） a）とb）との組合せ

例えば，手を紙に載せる場合，擦ったり拭ったりす る場合および鼻をかむ場合などいずれもこの 3 つの形 に分けて考觉ることができる。われわれは表 5 の要因

表 5 試験にとりあげた要因：０：実施

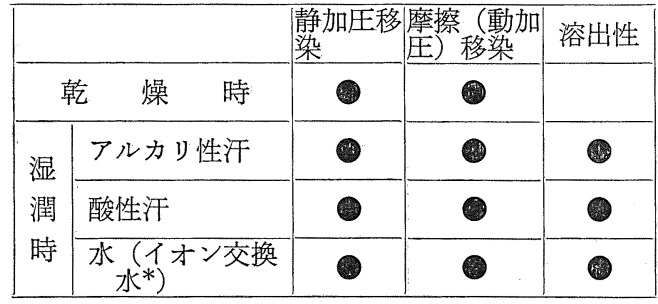

* 参考汇供試

昭和 48 年 11 月
をとり上げ単純化して試験した。

な特，人体分泌物には他に唾液などもあるが，再現 性ある代用液の調製が難しいので割愛した。

汗液は. JIS. L. 0848-1965 A法に準じ L-ヒスチジン 塩酸塩を含むアルカリ性和よび酸性人工汗液を用いた。 紙試料と接触させる人体皮膚の代用として精錬漂白済 みの正絹羽二重を採用した。

静加圧移染試験 一 筆記状態で手を静止する場合, 手の接触部分に加わる圧力は $20 \sim 40 \mathrm{~g} / \mathrm{cm}^{2}$ となる。 ここでは最高値の 2 倍の圧力を採用した。

試料面積： $25 \mathrm{~cm}^{2}$ 圧力・時間： $80 \mathrm{~g} / \mathrm{cm}^{2}$ 。 5 分

温度 $: 37^{\circ} \mathrm{C}$

乾燥試験 絹布を2つ折りとし，これを試料上に 載せ相対湿度 $60 \%$ の下で上述のように加圧。 後, 絹への螢光染料の移染度をブラック・ラ イト(紫外線登) 下で判定。

湿潤試験：絹布を所定の 試験液に浸し $100 \%$ 含水 率まで絞った後，乾燥試験に準じて移染試験 を行なら。

摩擦 (動加圧) 移染試験 一 筆記動作時に手の接 触部分に加わる圧力は $4 \sim 8 \mathrm{~g} / \mathrm{cm}^{2}$ である。ここでは その最高値を採用しつぎの摩擦条件を設定した。

接触 布: 絹布 $25 \mathrm{~cm}^{2}$

圧力: $8 \mathrm{~g} / \mathrm{cm}^{2}$

移動速度： $2 \mathrm{~cm} /$ 秒

反復移動距離： $20 \mathrm{~cm}$

反復回数：往復 5 回

温度： $20^{\circ} \mathrm{C}$

乾燥試験 試料上に接触布を置き，布に $200 \mathrm{~g} / 25$ $\mathrm{cm}^{2}$ の荷重を与光上記条件(相対湿度 $60 \%$ ) で布を移動させた。後，螢光染料の布への移 染度をブラック・ライト下で判定した。

湿潤試験 接触布を所定の 試験液に浸し $100 \%$ 含 水率になるように絞る。これを試料に載せ乾 燥試験に準じて操作する。

溶出性試験 一 紙製品が汗あるいは水に接触した 場合，実用時間内にどの程度溶出するかる調べた。試 料 $1 \mathrm{~g}$ を所定の試験液 $50 \mathrm{ml}$ 亿浸漬し， $25^{\circ} \mathrm{C}$ で 5 分間 処理。試料をとり出して後, 試験液に $\mathrm{NaCl} 0.1 \mathrm{~g}$ を 加光, 東洋沪紙 No. $51(8 \mathrm{~cm} \times 15 \mathrm{~cm})$ を浸し, 反 転させながら同温度で 1 時間処理して溶出した染料を 染着させる。その後, 風乾し染着染料量をブラック・ ライト下で判定した。

\section{1.2 判定基準}

厚生省告示昭和 41 年第 285 号「生理処理用品基準」 
本文III. 2. (4)执よび「生理処理用品基準註解」に基ず き，判定のためのスケールを調製し，これによって移 染度ならびに溶出度を判定した。（表6）

判定結果を表 7 によめて示す。

この試験では人体皮膚に代えて絹繊維を用いたが， 絹は皮膚よりも吸水, 吸着 (収着) 性が大きいので, 上記結果は実際に起り得るものよりも苛酷な結果と解 される。これらの結果はつぎのよらに要約できる。

（1）静止状態で紙が接触する場合は，たと元皮膚が 汗などで需れていても䖝光染料は移染しない。

（2）摩擦状態で接触する場合には，乾燥時は全く移 染しないが，湿潤時（汗ばんだ手で筆記する場合 など）はごく僅か移染する可能性がある。しかし， その程度は通常生理処理用品の規制值以下で，最 大でも規制値の 1.5 倍程度である。

（3）汗や水に浸漬した時の䖝光染料の溶出度は，用 途的に最も問題視される家庭用薄葉紙の場合で, ほとんどないかまたは生理用品としての規制值以 下である。上質紙，コート紙では生理用品規制值 以下のものが多いが，規制值を越えるものでも 3 倍未満である。もっとも移染量は溶出量の一部な ので，実際の移染量は上記結果に示されるように これらよりかなり少いものとなる。

なお，生理処理用品中の䖝光染料に対する厚生省の 規制は，螢光染料そのものを排除するというよりは， 䖝光染料が工業用製品であるために衛生的見地から規

\subsection{3 試験結果}

表 6 スケールの染色濃度および判定表示

\begin{tabular}{|c|c|c|}
\hline 染色濃度* & 判定表示 & 備 考 \\
\hline $0 \%$ & 0級 & \multirow{6}{*}{$\begin{array}{l}\text { ブラックライト下で無篣光 } \\
\text { 生理処理用品に対する规真制 } \\
\text { 值 }\end{array}$} \\
\hline 0.007 & 1 & \\
\hline 0.014 & 2 & \\
\hline 0.021 & 3 & \\
\hline 0.028 & 4 & \\
\hline 0.035 & 5 & \\
\hline
\end{tabular}

* 対汇紙重量

〈染色法〉東洋滤紙 No. $51(8 \mathrm{~cm} \times 15 \mathrm{~cm})$ を化成品工業協会增 白剤標品によって上記濃度で染色する。助剤: 食塩, $0.1 \mathrm{~g} / \mathrm{l}$, 液量： $50 \mathrm{~m} l$, 温度 $: 25^{\circ} \mathrm{C}$, 時間 : 60 分

制するものといわれている。したがって，筆記用紙， 図画用紙，チリ紙などは規制対象外とされているが， これらからの䖝光染料の移染性は非常に小さく，人体 に危険を与えるかも知孔ないと考光られる程の移染は 認め難い。

\section{4,2 木綿メリヤス下着からの人体移染性}

白の木綿メリヤス製品は, 通常䋐維重量当り $0.1 \%$ 〜 $0.2 \%$ のジアミノスチルベン・ジスルホン酸型螢光 染料で加工されている。メーカーを異にする木綿メリ ヤス下着（半袖をたはランニングシャツ）を市場で任 意に購入乙，5名の成人男子（20 歳台 4 名，30 歳台 1名）に夏期 20 時間連続着用させ, 着用中に $30 \sim 60$ 分間発汗をともなら運動をさせた。その後，これら男 子の腕, 背中特よび胸部にブラック・ライトを当て, 皮膚面からの䖝光発光の有無を調べた。

その結果, 少量の微

表 7 紙製品からの移染度および溶出度：級

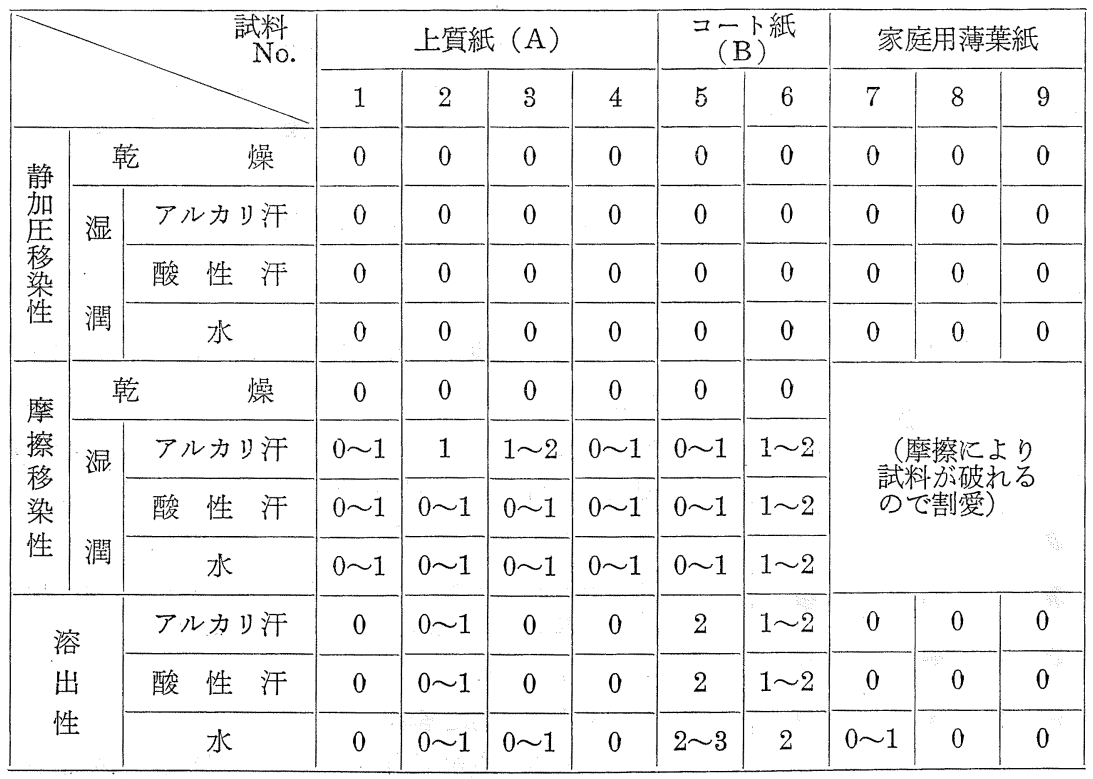
細繊維状のものが一部 附着し，これからの螢 光は認められたが，そ れ以外に皮膚面からの 螢光発光は認められな 加た。

メリヤス肌着は樹脂 加工など染料を固定す るような仕上加工は一 般に施されていないが， それでも皮膚移染を示 さないので, 衣料品か らの螢光染料の皮膚移 染は通常の着用ではほ とんど起らないものと 考光られる。 


\section{3 フキンからの食器移染性}

サンケイ新聞 (昭和 45 年 1 月 5 日) 飞, 䖝光増白さ れたフキンで食器を拭くと食器に螢光染料が附着する といら記事が載ったことがある。東京都内デパートで 䖝光増白されたフキン 2 種（ $\mathrm{S}$ 社，K社）を買求め, 実験室で螢光増白した木綿布（カナキン）とともに濡 れたガラス板を拭いた時の移染性を調べた。

実験室での螢光増白法一 市販フキン上の螢光染

料はジアミノスチルベン・ジスルホン酸型の 高親和性染料之推定されたので, 同様な構造 と性能をもつ下記染料を $0.2 \%$ 対木綿重量使 用し通常の吸尽法によって染色した。

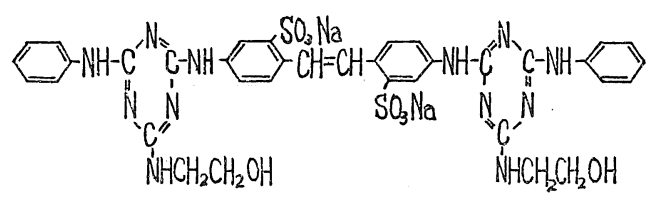

図 2 染料構造

これら 3 種の試料布をとれぞれつぎの 3 種の条件で 処理し，その処理布でもって水で濡らしたガラス板を 拭いた。

試料布の処理条件

(1) $20^{\circ} \mathrm{C}$ の水に浴比 $1: 100$ で 2 分間浸漬し, マングルで絞水率 $70 \%$ に脱水。

（2）(1)の条件で処理したものを $50 \sim 60^{\circ} \mathrm{C} て ゙$ 乾 燥。

(3) 台所洗剂 ( $\mathrm{L}$ 社) $1.75 \mathrm{~m} l / l$ の水溶液に浴比 1：100で $40^{\circ} \mathrm{C} \cdot 30$ 分間処理してから，脱水， 乾燥。

ガラス板をブラック・ライトで観察した結果を表 8 に示す。い゙れもガラス板からの䖝光は全く認められ なかった。

な扮参考までに，各処理布を气の5 倍重量の水飞浸 して絞った場合，茭り液中の螢光染料濃度は約 $10^{-4} \%$ であった。

結論として營光染料の食器移染の可能性は否定され

表 8 フキンからのガラス板に対する移染性

\begin{tabular}{|c|c|c|c|c|}
\hline 処理 & $\begin{array}{l}\text { コントロ } \\
\text { ール* }\end{array}$ & $\begin{array}{l}\text { S社フキ } \\
\text { 之 }\end{array}$ & $\begin{array}{l}\mathrm{K} \text { 社フキ } \\
\text { ソ }\end{array}$ & $\begin{array}{l}\text { 容験室増 } \\
\text { 严 }\end{array}$ \\
\hline (1) & $x$ & $x$ & $x$ & $x$ \\
\hline (2) & $x$ & $x$ & $x$ & $x$ \\
\hline$\ldots$ (3) & $x$ & $x$ & $x$ & $x$ \\
\hline
\end{tabular}

*末䖝光增白布 $\times:$ 䖝光なし

昭和 48 年 11 月
る。染色の物理化学的立場から考光ても，螢光染料が 全く親和性を示さないガラス質俰移染することは，容 易に考兑られないことであるう。

\section{5. むすび}

螢光染料の人体安全性をめぐる問題点について，わ れわれの知見の範囲でいくつかの観点から検討した。 結論は, 食品添加物に比較し得る程度に安全な化学品 ということができる。最近公表された通産省緘維品安 全対策会議の 報告24) 抢よび厚生省国立衛生試験所の 結論25) でも，発ガン性問題を含めて螢光染料の安全 性は確認されている。これはまた，米国 FDA がジア ミノスチルベン・ジスルホン酸型螢光染料のある種の ものを，食品包装用紙使うことを認可 ${ }^{26)}$ している ことからも首肯されよう。

な特，環境に対する安全性沉いて触れなかったが， ジアミノスチルベン・ジスルホン酸型螢光染料は，日 光や塩素などで比較的容易に分解され，かつ前記報文 3)によれば生物分解性もあるので，環境蓄積される 䫘念は少いものと考光られる。

\section{参 考文 献}

1）化成品工業協会染料委員会；繊維加工 $24 ， 1$ (No. 8) (1972)

2）前松；紙八技協誌，25，629（1971）

3）赤松・松尾；紙八゚技協誌，27，164（1973）

4）科学技術庁資源調查所；科学技術庁資源調查所資 料 第 11 号 (1970)

5）矢部・林；工化誌，60，740，1546 (1957) 工化誌，61，78，82 (1958)

6）化成品工業協会; 䖝光染料問題について（1970）

7) D. A. W. Adams ; J. Soc. of Dyers \& Colourists 75, 22 (1959)

8）大高；科学技術庁資源局資料 企画 122 衣料 1 , 35 (1967)

9）青山；毎日新聞読者の広場 6 月 24 日号 (1969)

10）寺山；繊維加工 [24，1（No. 8)（1972)] 加の 引用

11）橋田 - 竹村；第 46 回産業衛生学会, 第 14 回日本 産業医協議会 4 月 18 日 於大阪 (1973)

12) National Research Council (National Academy of Science, U.S.) ; Handbook of Toxicology Vol. 1

13）谷川・藤原；労働科学，31，829 (1955)

14，鈴木；関西医学，15，2029（1959）

15) F. H. Snyder et al; Toxicology \& Applied Phermacology 5, 176 (1963) 
16) H.C. Hodge et al; Toxicology \& Applied Phermacology 3, 689 (1961)

17) W. Jadassohn \& F. Schaaf; Dermatologica 140, 275 (1970)

18) W. Schneider \& R. Mirus; Archiv für Dermatology \& Syphilis 199, 401 (1955)

19) C. Gloxhuber et al; Archiv für Toxicology 19, 302 (1962)

20) Second Report of the Joint FAO/WHO Expart Committee on Food Additives; WHO Technical Report Series No. 144, (Rome, 1958)

21) Regulation of U.S. Foods and Drug Admi- nistration, Food Additives, Subpart A, 121.5 "Safety factors to be considered"

22) S. Neukomm \& M. De Trey; Medicina Experimentalis 4, 298 (1961)

23) F. Hoffmann \& D.C. R. Wohlfarth: Deutch Stomatologie 18, 647 (1968)

24）通産省繊維品安全対策会議；化学工業日報 3 月 18 日号 (1973)

25）国立衛生試験所；化学工業日報 7 月 30 日号 (1973)

26) Regulation of U.S. Food and Drug Administration, Food Additives, Subpart F, 121. 2535

\section{米国政府, ’73 OSAKA 国際公害防止ショウに参加}

主 催 日本工業新聞社。

後 援 環境庁，通商産業省，建設省，運輸省，大阪府，大阪市，大阪商工会議所。

日 時 昭和 48 年 11 月 7 日（水）—11月 12 日（月）。

会 場 大阪国際見本市港会場，第一号館。

\section{主要展示品目}

1) 分析, 測定機器。

2）化学薬品, 水処理装置, パイプ, ポンプ, バルブ。

3）大気拈よび他の気体污染防止用の機材と装置。水拈よび他の液体污染防止用の機材と装置。

4）固形廃棄物の処理抢よび再生用機材。

5）装置設計取付，応用，他のエンジニアリング・サービス。

照会先＼cjkstart東京都千代田区永田町 2-11-3

山王ホテル 107 号

電話 $5881-64471$

内線 107 